\title{
Social Architecture: An Emergency Management Case Study
}

\author{
Asif Qumer Gill \\ School of Software \\ University of Technology \\ Sydney, Australia \\ asif.gill@uts.edu.au
}

\author{
Sultana Lubna Alam \& Jessica Eustace \\ Discipline of IS and Accounting \\ University of Canberra \\ Canberra, Australia \\ \{lubna.alam, jessica.r.eustace\}@canberra.edu
}

\section{ABSTRACT}

Emergency management agencies are progressively using social media for the sourcing and distribution of disaster information. Emergency management agencies are often unsure as to how to best identify and assess social media concerns (e.g. information security, trust) which must be addressed to develop a social media-enabled disaster information management environment. This paper adopts the Social Architecture Viewpoint Assessment (SAVA) framework for identifying and assessing social media concerns from four different viewpoints: IT, Value, Resource and Management. This paper demonstrates the use of the SAVA framework in the context of an in-depth empirical case study of an Australian emergency management agency. The results of this study indicate that the SAVA framework is useful for emergency information management managers in identifying and assessing social media concerns.

Keywords: Crowd Sourcing, Disaster Management, Enterprise Architecture, Social Architecture, Social Media

\section{INTRODUCTION}

Disaster information management is a complex domain due to its diversity and dynamic characteristics (Othman and Beydoun 2013). Traditional disaster information management systems come under pressure when an unpredictable emergency situation causes these existing systems to breakdown (Semaan and Mark 2011). Social media, originated in the context of socialization (Parameswaran et al. 2007; Gill et al. 2011), has recently become very important in times of crisis (Grabowski and Roberts 2011; The Advertiser 2011; Eustace and Alam 2012). Social media provides new ways of supporting communities of people to source and share information during a crisis. It refers to systems that support the "activities, practices, and behaviours among communities of people who gather online to share information, knowledge, and opinions using conversational media" (Safko and Brake 2010). Data directly contributed by citizens and data gathered from disaster bystanders have a strongly positive potential to give responders more accurate and timely information than is possible with traditional information gathering methods (Tapia and Moore 2014). Recent examples of volunteer-gathered disaster information in emergency situations (e.g. the Haiti earthquake, San Diego fires, Hurricane Sandy, the Queensland floods) have triggered policy makers to reconsider the role of social media tools in disaster response (Majchrzak and More 2011). It has been observed that, throughout history, humans have demonstrated that, when faced with a disaster, they adapt whatever systems and skills offer help during a crisis (Sutton et al. 2011). This idea has been largely proven correct, as, most recently, emergency management agencies have begun to realize that they need to be connected to each other and with the community through social media systems (Foster 2013). 
For decades, emergency management agencies have operated with a centralized command structure, standard operating procedures, and internal vetting standards to ascertain appropriate responses to disasters (Tapia and Moore 2011). A central aspect of these organizational mechanisms is complete control over the internal flow of information concerning the crisis from source to organizational decision-maker, respectively, to ensure accuracy, security, legitimacy, and, eventually, trust between the organization and information source (Tapia and Moore 2011). However, social media systems are cloud-based Web 2.0 platforms that reside outside the emergency agency. Moreover, there are numerous challenges to the adoption of social media data, including issues of reliability, the quantification of performance, deception, focus of attention, non-verifiable sources and information, and the translation of reported observations/inferences to respond to crises (Tapia and Moore 2011; Starbird and Palen 2011). However, findings from recent comparative studies (cf. Tapia and Moore 2011) argue that social media data in crisis response already claims pockets of use and acceptance among organizations. They found that social media data is useful to responders in situations where information is limited, such as at the beginning of an emergency response effort, and when the risks of ignoring an accurate response outweigh the risks of acting on an incorrect one. These studies demonstrate that the barriers used by responding organizations have gone beyond discussions of trustworthiness and data quality to that of more operational issues.

There are a number of social media systems, such as SMS, mashups, wikis, Twitter, and Facebook that can be adopted by the emergency management agencies for information management. However, due to the varied nature of different social media systems and a lack of available scientific literature and practical tool support (Kerkhop 2012), emergency management agencies are often unsure how to best assess and use social media (Majchrzak and More 2011). If emergency management agencies are already using social media, they need to understand and be able to evaluate how well they are using social media, and, further, how they should be using social media to effectively establish a social media-enabled disaster information management environment. The effective establishment of the social mediaenabled disaster information management environment involves the continuous identification and assessment of different social media concerns or challenges (Terman 2011; Kerkhof 2012). Social media concerns must be addressed by the current or to-be developed social mediaenabled disaster information management environment. Against this backdrop, the key research question, in the context of Australian emergency management agencies, which is addressed in this paper, is as follows:

How to best identify and assess different social media concerns to effectively establish a social media-enabled disaster information management environment for the timely sourcing and distribution of disaster information?

In order to address the above research question, this paper adopts a Social Architecture Viewpoint Assessment (SAVA) framework. The SAVA (Gill and Bunker 2012) framework provides an assessment index and a conceptual model. The SAVA framework can be used to assist emergency management agencies to identify and assess social media concerns from four different viewpoints: IT, Value, Resource and Management. The framework is generic in nature and thus can be applied to all forms of social media platforms. This paper presents the use of the SAVA framework in the context of an Australian emergency management agency case study.

This paper is organized as follows. Firstly, it discusses the theoretical background and research context. Secondly, it provides an overview of the SAVA framework. Thirdly, it discusses the use of the SAVA framework in an Australian emergency management agency empirical case study. Finally, the empirical case study results are discussed along with the question of how the findings of this research can be further used in our current research. 


\section{THEORETICAL BACKGROUND AND RESEARCH CONTEXT}

Australia is a disaster-prone country and is frequently challenged by different types of emergency situations, such as floods and bush fires (e.g. Royal Commission Report 2011). Australian emergency management agencies are showing significant interest in the adoption of emerging social media (NSW SES Report 2011). Social media can be used by emergency management agencies for the sourcing of disaster information for planning and coordinating activities in response to disaster scenarios (Quillinan et al. 2009; Latonero and Shkovski 2010). For example, Twitter, as one of the social media tools, was used for disseminating Tsunami and flood warnings (Chatfield and Brajawidagda 2012). It has been reported that social media is mostly used during disaster response for information sharing (Horita et al. 2013). Gill et al. (2014) highlight that social media has been mostly used for fire and floods. However, social media is not restricted to any specific type of crisis and can be used in different crisis scenarios. A number of case studies on the use of social media in crisis management have been reported, such as the 2011 Canberra Mitchell factory fire (Eustace and Alam 2012), the 2010-2011 Queensland floods (Royal Commission Report 2011), the 2009 Oklahoma grassfires (Hughes 2009), and the 2007Virginia Tech shootings (Vieweg et al. 2008). Social media is a non-linear complex and distributed echo-system that involves a large number of independent parties who interact through different types of tools and channels. Unlike traditional disaster communication and warning systems (e.g. radio, TV), it provides a real-time distributed collaborative platform to government and the community for problem solving through content co-creation, sharing and evaluation (Chun and Reyes 2012).

Social media can be used along with existing traditional disaster management systems to help the emergency management agencies interact with citizens and non-government organizations in the context of sourcing and disseminating disaster information. However, emergency management agencies operate in a complex and highly regulated enterprise architecture environment. Enterprise architecture is the "organizing logic for business processes and IT infrastructure reflecting the integration and standardization requirements of the firm's operating model" (Ross et al. 2006). Enterprise architecture describes the building blocks of the formal business, information system and technology architecture domains of an enterprise (Harrison 2011). The current influx of emerging social media systems (Cross et al. 2005; Starbird and Stamberger 2010; Starbird and Palen 2011) provides both opportunities and challenges to the emergency management agencies who are used to linear and traditional enterprise architecture (Anderson, 2012). Emergency management is a multi-dimensional social system (Foster 2013). The emergency management agencies require the establishment of contemporary social media-enabled social architecture as part of their traditional enterprise architecture that needs to be supported through the continuous strategic adoption of social media. The social architecture domain is important for emergency management agencies in effectively understanding the communities of people who want to share information and opinions during a crisis.

Social architecture (based on the ISO/IEC 42010 architecture definition) is defined as the "fundamental concepts or properties of a social system in its environment embodied in its elements, relationships, and in the principles of its design and evolution" (Gill 2013). Social architecture refers to the social structure, behaviour and culture of communities of people who share information and opinions that influence the desired behaviours within and outside the operating environment of an enterprise. The social architecture of a social system can be designed by using an enterprise architecture framework. There are a number of enterprise architecture frameworks, such as the Zachman Framework (1987), Federal Enterprise Architecture Framework (CIO Council 2001), and the Open Group Architecture Framework (TOGAF 9.1) (Harrison 2011). TOGAF 9.1 is one of the most well-known and comprehensive architecture frameworks that claim to provide a complete architecture development method and guidelines for developing and managing the traditional business, system, and technologydomain architectures. Although TOGAF 9.1 is perhaps the most comprehensive enterprise architecture framework, it does not provide any support for developing and managing the emerging social architecture (see Figure 1). TOGAF 9.1, along with the other mentioned 
mainstream enterprise architecture frameworks, lacks support for identifying and assessing social media concerns, which is a fundamental step in the development of a social architecture.

Most recently, a meta-framework for adaptive enterprise service systems (Gill 2013) has been developed, which provides support for identifying and assessing social media concerns (assessment capability) to develop and improve the social architecture (operating capability). This meta-framework builds on multi-disciplinary action-design research in well-known enterprise requirements, strategy, architecture, service, and project management disciplines. This meta-framework uses the system of systems (Maier 1998), agility (Qumer and HendersonSellers 2008), and service science (Spohrer and Kwan 2009) theories to describe the modern enterprise as an "adaptive enterprise service system" (Gill 2013). This meta-framework includes a novel SAVA framework that provides an assessment index and a conceptual model to assist emergency management agencies in identifying and assessing social media-related concerns. The SAVA (Gill and Bunker 2012) construct is developed based on the recent literature and two disaster cases (2010 Haiti earthquake and 2010-11 Queensland floods). The SAVA framework has both a theoretical and practical foundation and is not tied to any specific social media. The SAVA index and a conceptual model can be applied to different social media in different organisational contexts. This paper adopts the SAVA framework and demonstrates its use in the context of an Australian emergency management agency case study. The next section discusses the SAVA framework.

\section{THE SAVA FRAMEWORK}

Emergency management agencies operate in a complex and highly-regulated environment. They need a framework for assessing social media concerns before making any long term commitments and investments in the strategic adoption of social media for their local context. In order to provide a practical approach for assessing social media concerns, this section discusses the SAVA framework. The SAVA framework has two main components: the SAVA Index (Table 1), and the SAVA Conceptual Model (Figure 1).

\subsection{The SAVA Index}

The SAVA index provides a list of 24 basic concern categories and assessment questions that can be used by emergency management agency information management managers to identify and assess social media concerns (Table 1). These basic concern categories can be divided into 15 sub-categories which can be further organised into 4 key themes or viewpoints on social media (see Table 1). These viewpoints are: social media value, social media resources, social media IT (Information Technology) and social media management viewpoints. The viewpoint theory (Harrison 2011) offers 5 key concepts: system, stakeholders, concerns, views and viewpoints. A system is a social media software system, platform or collection of components or tools (e.g. Twitter, Facebook) stakeholders are emergency management agency managers (e.g. digital media managers); concerns are the key social media challenges or interests (e.g. right information, right people, and information privacy) that are important to stakeholders a view represents the part of the system from the perspective of a related set of stakeholder's concerns; and a viewpoint is similar to a template that can be used to create a number of views for different stakeholders. 


\begin{tabular}{|c|c|c|c|}
\hline Ref. & Viewpoints & Major Categories & Basic Concern Categories \\
\hline \multirow[t]{5}{*}{01} & \multirow{5}{*}{$\begin{array}{l}\text { Social } \\
\text { Media } \\
\text { Value }\end{array}$} & \multirow[t]{2}{*}{ 01. Right Information } & 1. False Information and Rumours \\
\hline & & & 2. Bad Information Patterns \\
\hline & & \multirow[t]{2}{*}{ 02. Right People } & 3. Changing Demographics \\
\hline & & & 4. Information Source Trustworthiness \\
\hline & & 03. Right Time & 5. Information Latency \\
\hline \multirow[t]{3}{*}{02} & \multirow{3}{*}{$\begin{array}{l}\text { Social } \\
\text { Media } \\
\text { Resources }\end{array}$} & 04. Financial & 6. Information Overload \\
\hline & & 05. Human Resources & 7. Additional Resources and Supervision \\
\hline & & & 8. Performance Implications \\
\hline \multirow[t]{9}{*}{03} & \multirow{9}{*}{$\begin{array}{l}\text { Social } \\
\text { Media IT }\end{array}$} & 06. Infrastructure & 9. Information Unavailability \\
\hline & & 07. Integration & 10.Information Integration \\
\hline & & 08. Interoperability & 11. Information Interoperability \\
\hline & & 09. Privacy & $\begin{array}{l}\text { 12. Crowd-Sourced Information } \\
\text { Commingling }\end{array}$ \\
\hline & & \multirow[t]{3}{*}{ 10. Security } & 13. Malware \\
\hline & & & 14. Group Attack \\
\hline & & & 15. Distributed Denial-of-Service Attack \\
\hline & & 11. Scalability & 16. Content Constraint \\
\hline & & 12. Resilience & 17. Social Media “self-victims” \\
\hline \multirow[t]{7}{*}{04} & \multirow{7}{*}{$\begin{array}{l}\text { Social } \\
\text { Media } \\
\text { Manageme } \\
\text { nt }\end{array}$} & 13. Policy & 18. Lack of social media Monitoring Policy \\
\hline & & \multirow[t]{2}{*}{ 14. Process } & 19.Verification and Validation \\
\hline & & & $\begin{array}{l}\text { 20. Overwhelming Streams of Crowd- } \\
\text { Sourced Information }\end{array}$ \\
\hline & & \multirow[t]{4}{*}{ 15. Authority } & 21. Authority Confusion \\
\hline & & & 22. Ownership Confusion \\
\hline & & & 23. Unauthorised Information Sharing \\
\hline & & & $\begin{array}{l}\text { 24. Multiple or Too Many Sources of } \\
\text { Information }\end{array}$ \\
\hline
\end{tabular}

Table 1: The SAVA Index (Adopted from Gill and Bunker 2012) 


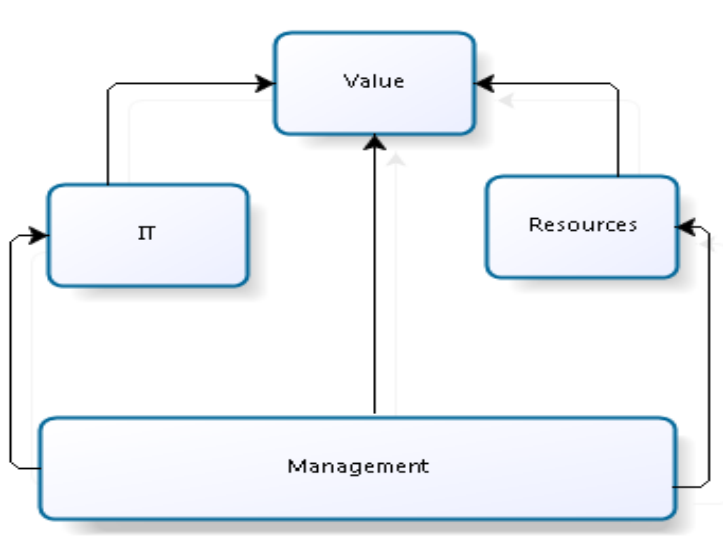

Figure 1: The SAVA Conceptual Model (Adopted from Gill and Bunker 2012)

\subsection{The SAVA Conceptual Model}

The SAVA conceptual model describes the grouping and relationships of the four key social media viewpoints of the SAVA index (see Figure 1). It can be observed from Figure 1 that the value for emergency management agency managers or stakeholders is in getting the right information from the right people to the right people at the right time in order to make quick, effective decisions during a crisis. The "Value" viewpoint of the SAVA conceptual model (see Figure 1) groups and represents the Right Information, Right People, and Right Time majorconcern categories. In order to obtain and deliver "Value", emergency management agencies need resources and IT. The "Resource" viewpoint groups the Financial and Human Resource major concern categories. The "IT" viewpoint groups the Infrastructure, Integration, Interoperability, Privacy, Security, Scalability and Resilience major-concern categories. The "Management" viewpoint provides the overarching management support to other viewpoints (e.g. IT Management, Resource Management, and Value Management). The "Management" viewpoint groups the Policy, Process and Authority major concern categories. The concern categories, major categories, and related viewpoints may also consider another two important aspects, namely (1) the likelihood and (2) the impact of the concern (Heath 1997). Likelihood is the possibility of social media concern, whereas Impact is how strongly the concern would affect emergency management agencies. Emergency management agencies can assess each concern listed under the major categories and give a score from 1 to 10 (e.g. from low to high) for the two dimensions of likelihood and impact. In this research, we adopted a qualitative descriptive case study approach and purposely did not use the quantitative score. This is because the purpose of this paper is to qualitatively generate information while answering the key research question: how to best identify and assess social media concerns? The next section discusses the use of the SAVA framework in an in-depth case study of an Australian emergency management agency.

\section{EMERGENCY MANAGEMENT CASE STUDY}

\subsection{The Case Study Organisation}

This section discusses the use of the SAVA framework in the naturalistic setting of an Australian emergency management agency case study organisation in Victoria, Australia (codenamed EMAX). A naturalistic setting allows the exploration of the performance or utility of a solution artefact or construction in its real environment. It is always empirical and may be interpretivist, positivist, and/ or critical (Pries-Heje et al 2008). This study presents a single empirical and interpretive in-depth analysis of the EMAX case study using SAVA. Yin (1994) argued that a case study approach is appropriate when the available or existing knowledge is not yet evident and when the focus is on real-life context. A case study approach can be used to analyse the information system in a case study organisation. The objective of this empirical case study is to demonstrate a practical approach to explain how to best identify and assess (analyse) social media (information system) concerns in the real context of an emergency 
management organisation (case study organisation as a unit of analysis). The 2009 Victorian Bushfires Royal Commission established the need for improved information flow between emergency management agencies and the community, calling on agencies to place as much value on warnings as they do on fire suppression. In 2011, the Victorian Flood Warnings and Response Review recommended actively pursuing the use of social media as part of emergency warning and public information systems. They also urged further trials to explore the use of social media as a credible source of information to and from the public during an emergency.

EMAX is one of the largest volunteer-based Australian emergency management agencies. EMAX has over 50,000 volunteers and over 1000 support personnel. EMAX has a collaborative culture that values volunteerism and strong collaboration and communication between the government and citizens. EMAX provides state-wide emergency coordination, community education, and response to major incidents in Australia and internationally such as the 2010-2011 Queensland floods and the 2011 Christchurch earthquake. EMAX is selected for this paper as a unit of analysis because it is a well-known agency within Australia which has made significant advances in its use of social media for emergency warnings and the provision of advice during major incidents. It won the ICT excellence in e-government award (i.e. Gov 2.0 category) from the Department of Financeand Deregulation in recognition of its excellence in institutionalizing social media use for disaster management.

EMAX has developed its social media capabilities and has made significant advances in its use of social media for warnings and advice during major incidents. These advances are part of a strategic initiative to help deliver the recommendations of the Royal Commission and accomplish EMAX's core mission of protecting lives and property. The initiative has resulted in EMAX's social media systems being integrated into the "One Source and One Message" system that delivers emergency warnings to agency websites/ emergency broadcasters. EMAX and the State Control Centre are now engaging directly with, and gathering intelligence from, the online community during major emergencies. This has played a significant role in meeting the Fire Services Commissioner's commitment to provide timely, relevant, and tailored advice to the community. It has also allowed a much quicker response to communication issues and has provided valuable intelligence to official emergency management structures.

\subsection{Empirical Analysis}

The case study organisation EMAX was engaged to participate in this empirical study. The SAVA framework was used as an analytical lens to collect and analyse qualitative data on social media in EMAX with an in-depth interview with EMAX's Digital Media manger. The SAVA construct was explained to EMAX's Digital Media manger. Additional information was also provided to the EMAX manager in order to clarify the SAVA framework. The Digital Media manager was used as a single source of data for this case study. This was sufficient because the Digital Media manager was across the social media use in EMAX and represented the EMAX social media team. Also, the questions did not relate to the Digital Media manager's personal beliefs, rather the questions were specific to social media and its use in EMAX. The assessment questions listed (derived from major and basic concern categories) in the SAVA Index provided a lens for analysing EMAX's capability to effectively adopt, operate, and improve social mediaenabled social architecture for real-time crowd-sourcing and the distribution of disaster information. For each major category of SAVA, additional social media concerns (if any) were also sought during the analysis. The researchers were also provided with the anonymous statistics of the users from the EMAX Facebook page and other extant documentation on EMAX (e.g. social media policy, web content) to provide additional context and support for the answers to relevant questions (e.g. questions relevant to social media policy). The next section discusses the empirical case study analysis results.

\subsection{Analysis Results}

The SAVA framework was used in identifying and assessing social media concerns in the real context of the case study organisation EMAX. A review of EMAX was carried out to identify the key social media concerns by using the four viewpoints and social media concerns listed in 
SAVA: social media value, social media resources, social media IT and social media management. This section discusses the research results.

\subsubsection{Social Media Value}

The social media value viewpoint groups and represents the Right Information, Right People, and Right Time major concern categories. These categories were used to review EMAX's social media-enabled social architecture from the value perspective. The value assessment results indicate that EMAX's current social media-enabled social architecture addresses most of the social media concerns listed under the social media Value viewpoint (see Table 2). It is also evident that the SAVA construct provided the essential criteria for facilitating the identification and assessment of social media concerns in the real context of EMAX. The results of this analysis are summarised below.

\begin{tabular}{|c|c|c|c|}
\hline Major Categories & $\begin{array}{c}\text { Basic Concern } \\
\text { Categories } \\
\end{array}$ & Assessment Questions & $\begin{array}{c}\text { Assessment Results } \\
\text { and Evidence }\end{array}$ \\
\hline \multirow[t]{2}{*}{$\begin{array}{l}\text { 01. Right } \\
\text { Information }\end{array}$} & $\begin{array}{l}\text { 1. False } \\
\text { Information and } \\
\text { Rumours }\end{array}$ & $\begin{array}{l}\text { Does it have the ability to } \\
\text { determine whether social } \\
\text { media-sourced information is } \\
\text { correct or not? }\end{array}$ & $\begin{array}{l}\text { EMAX uses the social } \\
\text { media monitor } \\
\text { officers and Hootsuite } \\
\text { system to determine } \\
\text { the correctness of the } \\
\text { social media sourced } \\
\text { information. }\end{array}$ \\
\hline & $\begin{array}{l}\text { 2. Bad } \\
\text { Information } \\
\text { Patterns }\end{array}$ & $\begin{array}{l}\text { Does it have the ability to } \\
\text { handle maliciously-generated } \\
\text { patterns of information? }\end{array}$ & $\begin{array}{l}\text { EMAX uses the social } \\
\text { media monitor } \\
\text { officers and Hootsuite } \\
\text { system to identify the } \\
\text { maliciously- } \\
\text { generated patterns of } \\
\text { information. }\end{array}$ \\
\hline \multirow[t]{2}{*}{ 02. Right People } & $\begin{array}{l}\text { 3. Changing } \\
\text { Demographics }\end{array}$ & $\begin{array}{l}\text { Does it have the ability to } \\
\text { determine whether the young } \\
\text { people are living in the disaster- } \\
\text { affected area and whether they } \\
\text { know to use social media in } \\
\text { order to receive information } \\
\text { from emergency management } \\
\text { agencies? }\end{array}$ & $\begin{array}{l}\text { EMAX perceives } \\
\text { that "Changing } \\
\text { Demographics" is } \\
\text { not a concern for } \\
\text { them. }\end{array}$ \\
\hline & $\begin{array}{l}\text { 4. Information } \\
\text { Source } \\
\text { Trustworthiness }\end{array}$ & $\begin{array}{l}\text { Does it have the ability to } \\
\text { determine whether the } \\
\text { information source is } \\
\text { trustworthy or not? }\end{array}$ & $\begin{array}{l}\text { EMAX uses the social } \\
\text { media monitor } \\
\text { officers and Hootsuite } \\
\text { system to determine } \\
\text { trustworthiness of the } \\
\text { information source. }\end{array}$ \\
\hline 03. Right Time & $\begin{array}{l}\text { 5. Information } \\
\text { Latency }\end{array}$ & $\begin{array}{l}\text { Does it have the ability to } \\
\text { handle or minimise delays in } \\
\text { the activity of raw information } \\
\text { translation from different } \\
\text { tweets or re-tweets? }\end{array}$ & $\begin{array}{l}\text { EMAX uses the social } \\
\text { media monitor } \\
\text { officers and Hootsuite } \\
\text { system. }\end{array}$ \\
\hline
\end{tabular}

Table 2: Social media Value Viewpoint Assessment Results

When assessing EMAX's current social media-enabled architecture using the SAVA criteria, it was found that EMAX uses the social media monitoring officers and Hootsuite system to 
address the concerns of false information, rumours, bad information patterns, information source trustworthiness, and information latency. EMAX has two specific roles in the state emergency control centre, one being the social media officer who ensures official notifications are sent out on Facebook and Twitter pages as well as maintaining an automated system that links to websites that have emergency warnings and information. The second role, an intelligence-gatherer, is activated to help with operations and decision-making during a crisis. The Hootsuite system is a social media management platform that manages profiles and data across multiple social networks and channels. It creates and schedule reports based on social media data to inform decision making and it also allows teams to collaborate. These roles and the Hootsuite system enable EMAX to search for certain keywords on social media sites, as well as monitor direct communications and direct activity, to maintain a correct, time-effective flow of information in order to make quick, effective decisions during a crisis. This helps EMAX to find misinformation (e.g. false information, rumours, and bad information patterns) quickly. This is critical because incorrect information could potentially put a community in danger. EMAX stresses the importance of having these roles as well as clear policies, processes and tools, in order to deal with misinformation.

The EMAX Digital media manager mentioned that social media has even assisted them to quell rumours. During recent emergencies, rumours were passed around that were incorrect and could have potentially put people in danger. EMAX would not have known or been able to monitor this. As people post these possible rumours on social media sites, EMAX can quickly verify or invalidate information.

The review of EMAX indicated that there is a slight lag time (e.g. information latency) between the piece of possible information being sourced and posted. This is because the sourced information must be first verified. However, in order to deal with the information-latency concern, EMAX has two additional roles, along with the Hootsuite system. The review of EMAX suggested that despite formal roles, policies, processes, and tools, EMAX has a policy of using informal language as much as possible in the context of social media during both emergency and non-emergency times. EMAX believes that "Changing Demographics" is not an issue for them, and they make their social media site pages appropriate for all ages and interests. It was evident from the Facebook page demographic data that people of all ages were accessing the Facebook page, with $8 \%$ in the $13-17$ age group, $24.2 \%$ in the $18-24$ age group, $28.6 \%$ in the $25-34$ age group, $21.3 \%$ in the $35-44$ age group, $11.5 \%$ in the $45-54$ age group, and $5 \%$ in the 55+ age group. It is assumed that the demographics were more spread due to the EMAX Facebook page being a government site.

\subsubsection{Social Media Resources}

The social media Resources viewpoint groups and represents both Financial and Human Resources' major concern categories. These categories were used to review EMAX from the resources viewpoint. The resource viewpoint assessment results indicate that EMAX clearly addresses the human resource concerns of the "additional resources and supervision concern category" (see Table 3). However, EMAX is still trying to determine how to address the information overload and performance concerns. It is also evident that SAVA provided the essential criteria (from the social media Resource viewpoint) for facilitating social media assessment in the real context of EMAX. The results of this analysis are summarised below. 


\begin{tabular}{|c|c|c|c|}
\hline $\begin{array}{c}\text { Major } \\
\text { Categories }\end{array}$ & $\begin{array}{c}\text { Basic } \\
\text { Categories }\end{array}$ & Assessment Questions & $\begin{array}{c}\text { Assessment } \\
\text { Results and } \\
\text { Evidence }\end{array}$ \\
\hline 04. Financial & $\begin{array}{l}\text { 6. Information } \\
\text { Overload }\end{array}$ & $\begin{array}{l}\text { Does it have the ability to } \\
\text { effectively handle overloaded } \\
\text { BigData coming via social } \\
\text { media streams and to get real } \\
\text { business value out of it (e.g., } \\
\text { opportunity cost)? }\end{array}$ & $\begin{array}{l}\text { EMAX is still } \\
\text { trying to } \\
\text { determine how to } \\
\text { deal with this } \\
\text { challenge. }\end{array}$ \\
\hline \multirow[t]{2}{*}{$\begin{array}{l}\text { 05. Human } \\
\text { Resources }\end{array}$} & $\begin{array}{l}\text { 7. Additional } \\
\text { Resources and } \\
\text { Supervision }\end{array}$ & $\begin{array}{l}\text { Does it have the ability to } \\
\text { manage and support the need } \\
\text { and cost of additional staff or } \\
\text { resources for monitoring, } \\
\text { updating, correcting, and } \\
\text { preventing the posting of } \\
\text { inaccurate information via } \\
\text { social media } 24 / 7 \text { ? }\end{array}$ & $\begin{array}{l}\text { EMAX has two } \\
\text { additional roles to } \\
\text { specifically } \\
\text { address the } \\
\text { challenge of } \\
\text { additional } \\
\text { resources and } \\
\text { supervision. }\end{array}$ \\
\hline & $\begin{array}{l}\text { 8. Performance } \\
\text { Implications }\end{array}$ & $\begin{array}{l}\text { Does it have the ability to } \\
\text { manage staff struggling to } \\
\text { keep up with an overload of } \\
\text { information, the impact on } \\
\text { their performance, and work } \\
\text { practices? }\end{array}$ & $\begin{array}{l}\text { EMAX is still } \\
\text { trying to } \\
\text { determine how to } \\
\text { deal with this } \\
\text { challenge. }\end{array}$ \\
\hline
\end{tabular}

Table 3: Social media Resources Viewpoint Assessment Results

EMAX has two additional roles specifically addressing the concerns of additional resources and supervision for monitoring, updating, correcting, and preventing the posting of inaccurate information via social media. EMAX stated that they have been discussing the information overload and performance-implication concerns in recent months. EMAX stated that there has been research into determining how to manage the noise-to-signal ratio. They are looking into research that is currently being conducted in natural-language processing to filter out the 'white noise' from social media-sourced information.

\subsubsection{Social Media IT}

The social media IT viewpoint groups and represents the Infrastructure, Integration, Interoperability, Privacy, Security, Scalability, and Resilience major concern categories. These categories were used to review EMAX from the IT perspective. The assessment results indicate (see Table 4) that EMAX clearly addresses all IT-related concerns. However, in the case of IT infrastructure and security-related concerns, EMAX mainly relies on social media service providers and other sources to distribute information. It is also evident that SAVA provided the essential criteria for facilitating the review of EMAX's social architecture concerns from the social media IT perspective. The results of this analysis are summarised below. 


\begin{tabular}{|c|c|c|c|}
\hline $\begin{array}{l}\text { Major } \\
\text { Categories }\end{array}$ & $\begin{array}{c}\text { Basic } \\
\text { Categories }\end{array}$ & Assessment Questions & $\begin{array}{l}\text { Assessment } \\
\text { Results and } \\
\text { Evidence } \\
\end{array}$ \\
\hline 06. Infrastructure & $\begin{array}{l}\text { 9. Information } \\
\text { Unavailability }\end{array}$ & $\begin{array}{l}\text { Does it have the ability to } \\
\text { handle information } \\
\text { unavailability due to power } \\
\text { failure or loss of mobile } \\
\text { phone or internet } \\
\text { connection or permanent/ } \\
\text { temporary service shut } \\
\text { down during a crisis? }\end{array}$ & $\begin{array}{l}\text { EMAX has a } \\
\text { contingency plan. }\end{array}$ \\
\hline 07. Integration & $\begin{array}{l}\text { 10. Information } \\
\text { Integration }\end{array}$ & $\begin{array}{l}\text { Does it have the ability to } \\
\text { handle integration } \\
\text { between the unstructured } \\
\text { BigData real-time streams } \\
\text { via social media and the } \\
\text { legacy system relational } \\
\text { database? }\end{array}$ & $\begin{array}{l}\text { Social media is } \\
\text { integrated with the } \\
\text { EMAX website, and } \\
\text { warning and } \\
\text { notification system. }\end{array}$ \\
\hline $\begin{array}{l}08 . \\
\text { Interoperability }\end{array}$ & $\begin{array}{l}\text { 11. Information } \\
\text { Interoperability }\end{array}$ & $\begin{array}{l}\text { Does it have the ability to } \\
\text { handle information } \\
\text { interoperability issues } \\
\text { between cloud-based social } \\
\text { media and legacy systems? }\end{array}$ & $\begin{array}{l}\text { Information is } \\
\text { interoperable } \\
\text { between social } \\
\text { media and the } \\
\text { EMAX warning and } \\
\text { notification system. }\end{array}$ \\
\hline 09. Privacy & $\begin{array}{l}\text { 12. Crowd- } \\
\text { Sourced } \\
\text { Information } \\
\text { Commingling }\end{array}$ & $\begin{array}{l}\text { Does it have the ability to } \\
\text { handle the possibility of } \\
\text { the commingling of crowd- } \\
\text { sourced information on an } \\
\text { entirely different crisis if } \\
\text { the information for both } \\
\text { crises is stored in a single } \\
\text { cloud-based multi-tenant } \\
\text { environment? }\end{array}$ & $\begin{array}{l}\text { EMAX refers to its } \\
\text { website for more } \\
\text { information on each } \\
\text { tweet they publish. } \\
\text { This information is } \\
\text { time stamped on the } \\
\text { EMAX website, } \\
\text { thereby minimising } \\
\text { the impact of } \\
\text { commingling, as } \\
\text { much as possible. }\end{array}$ \\
\hline \multirow[t]{2}{*}{ 10. Security } & 13. Malware & $\begin{array}{l}\text { Does it have the ability to } \\
\text { block the access of } \\
\text { malicious software that } \\
\text { may view and modify the } \\
\text { social media-sourced } \\
\text { information packets in } \\
\text { transit? }\end{array}$ & $\begin{array}{l}\text { EMAX relies on the } \\
\text { social media service } \\
\text { provider and other } \\
\text { sources. }\end{array}$ \\
\hline & $\begin{array}{l}\text { 14. Group } \\
\text { Attack }\end{array}$ & $\begin{array}{l}\text { Does it have the ability to } \\
\text { handle a brute force attack } \\
\text { that may manipulate the } \\
\text { encrypted user's social } \\
\text { media account information } \\
\text { and their broadcasted } \\
\text { messages or tweets? }\end{array}$ & $\begin{array}{l}\text { EMAX relies on the } \\
\text { social media service } \\
\text { provider and other } \\
\text { sources. }\end{array}$ \\
\hline
\end{tabular}




\begin{tabular}{|c|c|c|c|}
\hline $\begin{array}{c}\text { Major } \\
\text { Categories }\end{array}$ & $\begin{array}{c}\text { Basic } \\
\text { Categories }\end{array}$ & Assessment Questions & $\begin{array}{c}\text { Assessment } \\
\text { Results and } \\
\text { Evidence }\end{array}$ \\
\hline & $\begin{array}{l}\text { 15. Distributed } \\
\text { Denial-of- } \\
\text { Service Attack }\end{array}$ & $\begin{array}{l}\text { Does it have the ability to } \\
\text { handle an attack targeting } \\
\text { specific social media } \\
\text { websites by flooding a web } \\
\text { server with repeated } \\
\text { tweets or messages? }\end{array}$ & $\begin{array}{l}\text { EMAX relies on the } \\
\text { social media service } \\
\text { provider and other } \\
\text { sources. }\end{array}$ \\
\hline 11. Scalability & $\begin{array}{l}\text { 16. Content } \\
\text { Constraint }\end{array}$ & $\begin{array}{l}\text { Does it have the ability to } \\
\text { effectively operate within } \\
\text { the maximum 140- } \\
\text { character tweet content } \\
\text { size? }\end{array}$ & $\begin{array}{l}\text { EMAX refers to its } \\
\text { website for more } \\
\text { information on each } \\
\text { short tweet they } \\
\text { publish. }\end{array}$ \\
\hline 12. Resilience & $\begin{array}{l}\text { 17. Social Media } \\
\text { "self-victims" }\end{array}$ & $\begin{array}{l}\text { Does it have the ability to } \\
\text { effectively operate if the } \\
\text { social media service suffers } \\
\text { due to a disaster (e.g., } \\
\text { emergency management } \\
\text { agencies dependent on } \\
\text { social media may not be } \\
\text { able to access the } \\
\text { information posted on the } \\
\text { social media site)? }\end{array}$ & $\begin{array}{l}\text { EMAX has a } \\
\text { contingency plan to } \\
\text { deal with social } \\
\text { media service } \\
\text { interruptions and } \\
\text { issues. }\end{array}$ \\
\hline
\end{tabular}

Table 4: Social Media IT Viewpoint Assessment Results

EMAX has well-established warning and notification systems, and the social media system is only a part of their overall enterprise architecture. All warnings and notifications are published on its website. EMAX makes use of the emergency alert system and official emergency broadcast stations like the Australian Broadcasting Corporation (ABC). The integrated EMAX website and the warning and notification system of their information-management architecture seem to address the concerns of information integration and interoperability. EMAX tries to distribute as much information as possible in one tweet; however, this sometimes might not be sufficient. Therefore, in order to address this scalability concern, EMAX has found a way to link back the small tweet description to the EMAX website on Twitter. EMAX refers to its website for more information on each tweet they publish. This information is also time-stamped on the EMAX website to minimise commingling as much as possible. With concerns such as Malware, Group Attacks, Distributed Denial of Service Attacks, and the unavailability of social media sites such as Twitter, EMAX mainly relies on other sources to distribute information. EMAX also has contingency plans in case they themselves end up in an emergency situation which may require them to relocate to an alternative location. EMAX emphasised that social media is a mobile medium and can be accessed from anywhere on any Internet-enabled device, including a mobile phone. The social media officers are not tied to any computer system and can do their job from anywhere if needed; they are not necessarily reliant on only agency-based networks to do their work. EMAX, overall, seems well-placed in dealing with theIT-related concerns outlined in the SAVA construct.

\subsubsection{Social Media Management}

The social media Management viewpoint groups and represents the Policy, Process and Authority major concern categories. These categories were used to review EMAX from the management perspective. The assessment results indicate (see Table 5) that EMAX addresses most of the concerns listed under the management viewpoint. It is also evident that SAVA 
provided the essential criteria for facilitating the review of EMAX's architecture concerns from the social media management viewpoint. The results of this analysis are summarised below.

\begin{tabular}{|c|c|c|c|}
\hline $\begin{array}{c}\text { Major } \\
\text { Categories }\end{array}$ & $\begin{array}{c}\text { Basic } \\
\text { Categories }\end{array}$ & Assessment Questions & $\begin{array}{c}\text { Assessment } \\
\text { Results and } \\
\text { Evidence } \\
\end{array}$ \\
\hline 13. Policy & $\begin{array}{l}\text { 18. Lack of Social } \\
\text { Media Monitoring } \\
\text { Policy }\end{array}$ & $\begin{array}{l}\text { Does it have a clear policy to use } \\
\text { and monitor social media in a } \\
\text { specific situation? }\end{array}$ & $\begin{array}{l}\text { EMAX has a social } \\
\text { media policy. }\end{array}$ \\
\hline \multirow[t]{2}{*}{ 14. Process } & $\begin{array}{l}\text { 19. Verification and } \\
\text { Validation }\end{array}$ & $\begin{array}{l}\text { Does it have the ability to verify } \\
\text { and validate the information } \\
\text { sourced via social media streams? }\end{array}$ & $\begin{array}{l}\text { EMAX has specified } \\
\text { roles, processes and } \\
\text { tools to verify and } \\
\text { validate social media- } \\
\text { sourced information. }\end{array}$ \\
\hline & $\begin{array}{l}\text { 20. Overwhelming } \\
\text { Streams of Crowd- } \\
\text { Sourced } \\
\text { Information }\end{array}$ & $\begin{array}{l}\text { Does it have clear processes that } \\
\text { guide how, when, and how often } \\
\text { the streaming of social media- } \\
\text { sourced data between the social } \\
\text { media and legacy systems should } \\
\text { occur? }\end{array}$ & $\begin{array}{l}\text { EMAX does not seem } \\
\text { to have a clear } \\
\text { process to address } \\
\text { this concern. }\end{array}$ \\
\hline \multirow[t]{4}{*}{ 15. Authority } & $\begin{array}{l}\text { 21. Authority } \\
\text { Confusion }\end{array}$ & $\begin{array}{l}\text { Does it have the ability to handle a } \\
\text { situation where social media } \\
\text { providers change their terms and } \\
\text { polices at their own will? }\end{array}$ & $\begin{array}{l}\text { EMAX has to rely on } \\
\text { the third-party social } \\
\text { media service } \\
\text { provider at this stage. }\end{array}$ \\
\hline & $\begin{array}{l}\text { 22. Ownership } \\
\text { Confusion }\end{array}$ & $\begin{array}{l}\text { Does it has a clear understanding } \\
\text { of who owns the information } \\
\text { residing in the cloud-based social } \\
\text { networks, whether that be the } \\
\text { community, social media vendor } \\
\text { or emergency services? }\end{array}$ & $\begin{array}{l}\text { EMAX has to rely on } \\
\text { the third-party social } \\
\text { media service } \\
\text { provider at this stage. }\end{array}$ \\
\hline & $\begin{array}{l}\text { 23. Unauthorised } \\
\text { Information } \\
\text { Sharing }\end{array}$ & $\begin{array}{l}\text { Does it have a clear } \\
\text { understanding as to who has } \\
\text { rights to grant permissions to } \\
\text { share and secure the information } \\
\text { sourced via social media (e.g., } \\
\text { who may create or close threads } \\
\text { for communication in social } \\
\text { media)? }\end{array}$ & $\begin{array}{l}\text { EMAX's online } \\
\text { channels, including } \\
\text { social media } \\
\text { platforms, must be } \\
\text { authorised by the } \\
\text { Executive Manager, } \\
\text { Strategic } \\
\text { Communications. } \\
\end{array}$ \\
\hline & $\begin{array}{l}\text { 24. Multiple or Too } \\
\text { Many Sources of } \\
\text { Information }\end{array}$ & $\begin{array}{l}\text { Does it have the ability to control } \\
\text { which media website or thread to } \\
\text { follow, and manage the situation } \\
\text { if someone shuts down a popular } \\
\text { thread? }\end{array}$ & $\begin{array}{l}\text { EMAX authorised } \\
\text { official } \\
\text { representatives to } \\
\text { disclose that they are } \\
\text { EMAX members or } \\
\text { contractors. EMAX } \\
\text { also has multiple } \\
\text { channels and could } \\
\text { still operate if } \\
\text { someone shut down a } \\
\text { popular thread. }\end{array}$ \\
\hline
\end{tabular}

Table 5: Social Media Management Viewpoint Assessment Results

EMAX has a social media policy that applies to all EMAX members and external contractors who use social media professionally and personally. EMAX has a process to support their policy that defines its obligations with regard to online comments and social media use and to raise awareness among members who make comments via social media platforms. The social media 
process suggests that EMAX members cannot comment as official representatives of EMAX unless they are authorised to do so. When engaging with social media, the authorised official representative must disclose that they are an EMAX member or contractor. The authorised members must disclose and comment only on information classified as public domain information and take all reasonable measures to ensure that online content is accurate and not misleading. The official EMAX online channels have a moderation policy in place that outlines what content and conduct is considered acceptable and what action will be taken if policies are breached. All websites established as official EMAX online channels, including social media platforms, must be authorised by the Executive Manager, Strategic Communications. EMAX stated that, in order to gain credibility with over 100,000 followers on social media sites, EMAX has had to have a social media presence for a number of years as well as having a media unit to gain credibility offline as well. EMAX has social media officers and the Hootsuite system to monitor social media sites to verify and validate information. In summary, the overall empirical case study analysis results suggest that EMAX has a well-established social mediaenabled social architecture that addresses most of the concerns listed in the SAVA index.

\section{DISCUSSION: LIMITATIONS AND CONTRIBUTION}

A number of case studies regarding the use of social media during a crisis have been reported in the past. Most of the existing research studies are focused around the use of social media and its benefits during a crisis (Sutton et al. 2011). Emergency management agencies are still learning about the ramifications of the use of social media and are not sure how to best assess and use it. This paper takes a critical viewpoint and discusses the social media concerns in the context of an Australian emergency management agency. This paper adopted SAVA, as a systematic analytical framework, to identify and assess social media concerns in the context of the Australian case study organisation, EMAX. The SAVA framework provided an analytical lens through tables (Table 2-5) that contain key concern categories, major categories and viewpoints. The SAVA construct is focused on the social media concerns related to an emergency management agency's social architecture. However, SAVA is not limited to any particular social media. The use of SAVA in the Australian emergency management agency case study gave us a number of insights into social media adoption in emergency management agencies. It can be observed from the results that SAVA lays the foundation of how one might rationally approach the assessment of social media concerns, which are critical for developing or updating social architecture for the real-time sourcing and distribution of disaster information. The SAVA construct, by no means, is an exhaustive criteria list (e.g. categories) of social media concerns. Since the literature and practice are dynamic, SAVA should be considered as an evolving construct; and it should be revised and extended by emergency management agencies to suit their local context.

The use of a single case study could also be considered a limitation when generalizing the analysis results. However, the case study selected for this empirical analysis is a well-known organisation with advanced social media capabilities and architecture. The case study organization has been using social media for a number of years. The review of EMAX through the lens of SAVA indicated that EMAX has a mature architecture and approach to social media usage for the crowd-sourcing and distribution of disaster information. EMAX's current architecture addressed most of the concerns outlined in SAVA. EMAX realises that some of the architecture concerns mentioned in SAVA require attention and that they need to address those concerns. Through this analysis, it was found that social media systems like Facebook and Twitter are only one part of their public information strategy and social architecture. EMAX makes sure that it is not reliant on only one form of public information. It is interesting to note that EMAX has two additional roles within the emergency co-ordination centre dedicated to social media intelligence gathering and posting. From thereview and observations made on the EMAX Facebook page, the EMAX Connect page, and the EMAX Twitter account, EMAX has definitely moved away from the notion of being a gatekeeper to being that of a translator, as mentioned in the literature review and the social media tool (e.g. 5. Information Latency) and has a collaborative approach to engage with their followers on each page and 
welcome discussion and inquiry to clear up incorrect information. It is also interesting to note that people of all ages follow EMAX on Facebook, contradictory to the perceived notion that 'young' people would be more interested in using social media. The EMAX Connect website is also interesting, as it is dedicated exclusively to EMAX-related materials with Web 2.0 elements such as blogs, videos and photos, and live online forums to which members of EMAX can contribute. Members of EMAX contribute photos and videos of training exercises and blog posts about fire brigade news. EMAX Connect appears to be similar to a Facebook for emergency services personnel and members of the public who are also interested in EMAX activities. It appears that EMAX is quite mature in relation to social media usage. Governments, policy makers, and other emergency management agencies should consider the EMAX empirical case study analysis as an example of how to effectively assess and adopt social media. Based on the analysis results presented in this paper, we can offer the following practical recommendations:

- $\quad$ Create the roles of social media intelligence gatherers and general social media officers and have these positions on standby in the event of an emergency

- $\quad$ Provide more support, resources, and encouragement to use social media within emergency management agencies

- $\quad$ Communicate and collaborate with social media providers such as Facebook and Twitter so these social media providers can help during an emergency

- $\quad$ Develop the ability to automatically post information from an official website to Twitter and Facebook for strong information integration and interoperability

This research presents previously unavailable social media viewpoints and concerns. The identified social media viewpoints and concerns, if not all, could be considered a research theme. For example, consider the following concerns by category: Changing Demographics, Information Source Trustworthiness, Lack of Information Interoperability, Crowd-Sourced Information Commingling, Information Overload and Social Media "self-victims." One may be interested in researching and proposing theories or constructs for checking the informationsource trustworthiness. Others may be interested in researching information overload and its impact on human and financial resources. This paper purposely did not discuss social media hype and benefits in great detail; rather, it adopted a systemic SAVA approach in order to identify and assess social media concerns. In our future research, we intend to investigate the "Information Source Trustworthiness" concern category to further explore trusted social architecture. In summary, social media is simply another system through which to source and disseminate disaster information. It is, essentially, making sure that communities stay informed during a disaster situation. Based on the analysis presented in this paper, it can be suggested that social media systems should be considered a part of the whole solution for creating informed and resilient communities.

\section{CONCLUSION}

This paper presented an in-depth case study of an Australian emergency management agency with the help of SAVA. The results of the case study indicate that SAVA seems useful in providing necessary criteria questions to identify and assess the social media concerns of the existing or to-be-developed emergency management social architecture. This case study provided a deeper insight into social media concerns, which must be carefully identified, assessed, and addressed by emergency management agencies. The case study results indicate that the case study organisation, EMAX, was able to identify and assess all of the social architecture concerns through the use of SAVA. Social media concern assessment is, of course, not an easy task, and emergency management agencies may tailor and extend the SAVA construct and include their own criteria for the assessment of social media concerns. This paper aims to reduce the uncertainty of emergency management agencies and increase understanding of how to identify and assess social media concerns. On the basis of the empirical case study, it is concluded that SAVA is useful for identifying and assessing social 
media concerns for developing or updating social architecture. However, SAVA needs to be considered with a view of its limitations, since the body of literature and practices are both dynamic in nature, and it should thus be considered an on-going construct to be revised and extended by emergency management agencies and researchers. In future, we intend to extend our research into the trusted social architecture viewpoints and concerns of SAVA.

\section{ACKNOWLEDGEMENTS}

We are thankful to people from the emergency management agencies who helped us with their valuable feedback and experience.

\section{REFERENCES}

Chatfield, A.T. and Brajawidagda, U. (2012) "Twitter Tsunami Early Warning Network: A Social Network Analysis of Twitter Information Flows", Twenty-third Australasian Conference on Information Systems, Geelong Australia, Deakin University

CIO Council (2001) A Practical Guide to Federal Enterprise Architecture, Version 1.0. US Government Accountability Office (GAO). Available from: http:// www.gao.gov/products/P00201

Cross, R., Liedtka, J. and Weiss, L. (2005) A practical guide to social networks. Harvard Business Review. Available from: https:// hbr.org/2005/ 03/a-practical-guide-to-socialnetworks

Eustace, J . and Alam, Su. (2012). "Tweeting from the danger zone: The use of Twitter by emergency agency during Mitchell factory fire in Canberra", MCIS 2012 Proceedings. Paper 27.

Foster, H. (2013). Interactive hazard preparation strategy efficacy: consideration for future community engagement programs. Australian Journal of Emergency Management, 28(1), 8-14.

Gill, A.Q., Bunker, D. and Seltsikas, P. (2011) An Empirical Analysis of Cloud, Mobile, Social and Green Computing: Financial Services IT Strategy and Enterprise Architecture. 2011 IEEE Ninth International Conference on Dependable, Autonomic and Secure Computing, Sydney, Australia.

Gill A.Q. and Bunker, D. (2012) Crowd Sourcing Challenges Assessment Index for Disaster Management. Proceedings of the Americas Conference on Information Systems, Seattle, United States.

Gill, A.Q. (2013). Towards the Development of an Adaptive Enterprise Service System Model. Proceedings of the Americas Conference on Information Systems, Chicago, USA.

Gill, A.Q., Alam, S. and Eustace, J . (2014) Using Social Architecture to Analyzing Online Social Network Use in Emergency Management". Proceedings of the Americas Conference on Information Systems, Savannah, USA.

Grabowski, M. and Roberts., K. (2011) High reliability virtual organizations: Co-adaptive technology and organizational structures in tsunami warning systems. ACM Trans. Comput.-Hum. Interact. 18(4).

ISO/IEC 42010. Systems and software engineering - Architecture description: Defining architecture [Online]. Available from: http://www.iso-architecture.org/ieee1471/defining-architecture.html.

Harrison, R. (2011). TOGAF Foundation. The Open Group.

Heath, L. R. (1998) New Communication Technologies: An issue management point of view, Public Relations Review, 24(3), 273-288. 
Horita, F., Degrossi, L., Assis, L., Zipf, A., Albuquerque, J. (2013) "The use of volunteered geographic information and crowdsourcing in disaster management: a systematic literature review", Proceedings of the 19th AMCIS, Chicago, Illinois.

Hughes, A. (2009) Twitter Adoption and Use in Mass convergence and emergency events, University of Colorado: Bolder.

Kerkhof, J.V.d. (2012). Towards a social media maturity model. Master's Thesis. Utrecht University.

Latonero, M.and Shklovski, I. (2010). Respectfully Yours in Safety and Service - Emergency Management \& Social Media Evangelism. SSRN: http:// ssrn.com/ abstract=1566423.

Maier, M.W. (1998) Architecting principles for system of systems. Systems Engineering. 1(4), 267-284.

Majchrzak, A and More, P.H.B. (2011). Emergency! Web 2.0 to the rescue. Communications of the ACM, 54(4), 125-132.

NSW SES Report (2011) The capacity of communications networks and emergency warning systems to deal with emergencies and natural disasters. Environment and Communications References Committee, Canberra.

Othman. S.H., and Beydoun, G. (2013). Model-driven disaster management. J ournal of Information and Management. 50(5) 218-228.

Parameswaran, M., Whinston, A.B. (2007) Social computing: an overview, Communications of the Association for Information Systems, 19, 762-780.

Pries-Heje, J ., Baskerville, R., and Venable, J .R. (2008) Strategies for design science research evaluation. The 16th European Conference on Information Systems (ECIS), Galway, Ireland.

Quillinan, T.B., Brazier, F., Aldewereld, H. Dignum, F., Dignum, V., Pen serini, L., Wijngaards, N. (2009) Developing agent-based organizational models for crisis management, International conference on AAMAS, Budapest, Hungry, 45-52.

Qumer, A. and Henderson-Sellers, B. (2008). An Evaluation of the Degree of Agility in Six Agile Methods and its Applicability for Method Engineering. J ournal of Information and Software Technology , 50(4), 280-295.

Royal Commission Report. (2011) Queensland floods commission inquiry - interim report [Internet]. Available from: www.floodcommission.qld.gov.au

Ross, J.W. Weill, P, and Robertson, D. (2006). Enterprise architecture as strategy: Creating a foundation for business execution. Harvard Business Review Press.

Semaan, B., and Mark, G. (2011) Technology-mediated social arrangements to resolve breakdowns in infrastructure during ongoing disruption. ACM Transactions on Computer-Human Interaction (TOCHI), 18(4), article 21.

Spohrer, J . \& Kwan, S. K. (2009) Service science, management, engineering, and design (SSMED): An emerging discipline - outline \& references. International J ournal of Information Systems in the Service Sector, 1(3), 1-31.

Starbird, K. \& Palen, L. (2011) "Voluntweeters:” Self-organizing by digital volunteers in times of crisis, Proceedings of the ACM 2011 Conference on Computer Human Interaction, Vancouver, BC, Canada.

Starbird, K. \& Stamberger, J .T. (2010) Tweak the tweet: leveraging microblogging proliferation with a prescriptive syntax to support citizen reporting, Proceedings of the Information Systems for Crisis Response and Management, Seattle, USA.

Safko, L., and Brake, D. (2010). The social bible. Hoboken (NJ ). J ohn Wiley \& Sons, Inc. 
Sutton, J ., Hansard, B., and Hewett, P. (2011). Changing channels: communicating tsunami warning information in Hawaii. The 3rd International J oint Topical Meeting on Emergency Preparedness and Response, Robotics, and Remote Systems. Knoxville, Tennessee.

Tapia, A. \& Moore, K. (2014) Good Enough is Good Enough: Overcoming Disaster Response Organizations' Slow Social Media Data Adoption. Proceedings of Computer Supported Cooperative Work.

Terman, E. (2011) Five top challenges of integrating social media data with business applications [Internet]. Available from: http://www.ctoedge.com/content/five-topchallenges-integrating-social-media-data-business-applications

The Advertiser. (2011). CFS to use Twitter and Facebook for bushfire warnings [Internet]. Available from: http:// www.adelaidenow.com.au/ first-ban-of-fire-season-for-sa-northeast-pastoral-district/story-e6frea6u-1226140282012

Vieweg, S,Palen L,Lui S,Hughes, Sutton J . (2008) Collective Intelligence in Disaster: Examination of the Phenomenon in the aftermath of the 2007 Virginia tech shootings, University of Colorado: Boulder

Yin, R.K. (1994) Case study research: design and methods, SAGE Publications.

Zachman, J.A. (1987) A framework for information systems architecture. IBM Systems J ournal, 26, 276-292.

Copyright: (C) 2015 Gill, Alam \&Eustace. This is an open-access article distributed under the terms of the Creative Commons Attribution-NonCommercial 3.0 Australia License, which permits non-commercial use, distribution, and reproduction in any medium, provided the original author and AJ IS are credited.

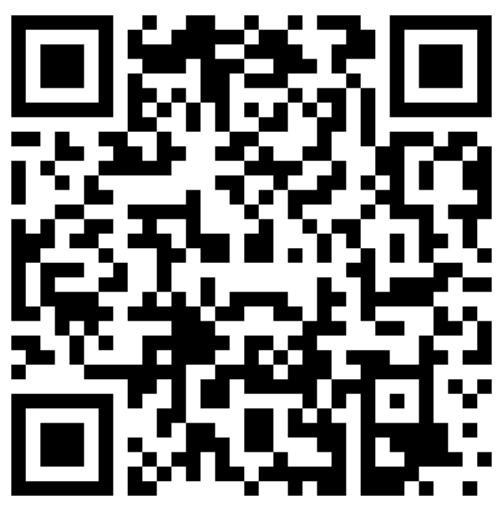

